\title{
Thiourea-Based fluorescent chemosensors for aqueous metal ion detection and cellular imaging
}

Vonlanthen, Mireille ; Connelly, Colleen M ; Deiters, Alexander ; Linden, Anthony ; Finney, Nathaniel S

\begin{abstract}
We describe three significant advances in the use of thioureas as reporting elements for metalresponsive fluorescent chemosensors. First, on the basis of the crystal structure of a chemosensor analogue, we provide a deeper understanding of the details of the thiourea coordination environment. Second, we describe a new generation of chemosensors with higher affinities for $\mathrm{Zn} 2+$ and $\mathrm{Cd} 2+$ than were observed for earlier probes, expanding the scope of this type of probe beyond $\mathrm{Hg} 2+$ detection. Third, we show that a thiourea-based chemosensor can be employed for fluorescence microscopy imaging of $\mathrm{Hg} 2+$ ion concentrations in living mammalian cells.
\end{abstract}

DOI: https://doi.org/10.1021/jo500710g

Posted at the Zurich Open Repository and Archive, University of Zurich ZORA URL: https://doi.org/10.5167/uzh-100368

Journal Article

Accepted Version

Originally published at:

Vonlanthen, Mireille; Connelly, Colleen M; Deiters, Alexander; Linden, Anthony; Finney, Nathaniel S (2014). Thiourea-Based fluorescent chemosensors for aqueous metal ion detection and cellular imaging. Journal of Organic Chemistry, 79(13):6054-6060.

DOI: https://doi.org/10.1021/jo500710g 


\section{Thiourea-based fluorescent chemosensors for aqueous metal ion detection and cellular imaging}

Mireille Vonlanthen ${ }^{a}$, Colleen M. Connelly ${ }^{b}$, Alexander Deiters ${ }^{b, c}$, Anthony Linden ${ }^{a}$ and Nathaniel S. Finney ${ }^{a, b, *}$

${ }^{a}$ Department of Chemistry, University of Zurich, Zurich $\mathrm{CH}-8057$ (Switzerland).

${ }^{b}$ Department of Chemistry, North Carolina State University, Raleigh, NC 27695 (USA). nsfinney@ncsu.edu

${ }^{c}$ Department of Chemistry, University of Pittsburgh, Pittsburgh, PA 15260 (USA).

Table of Contents Graphic

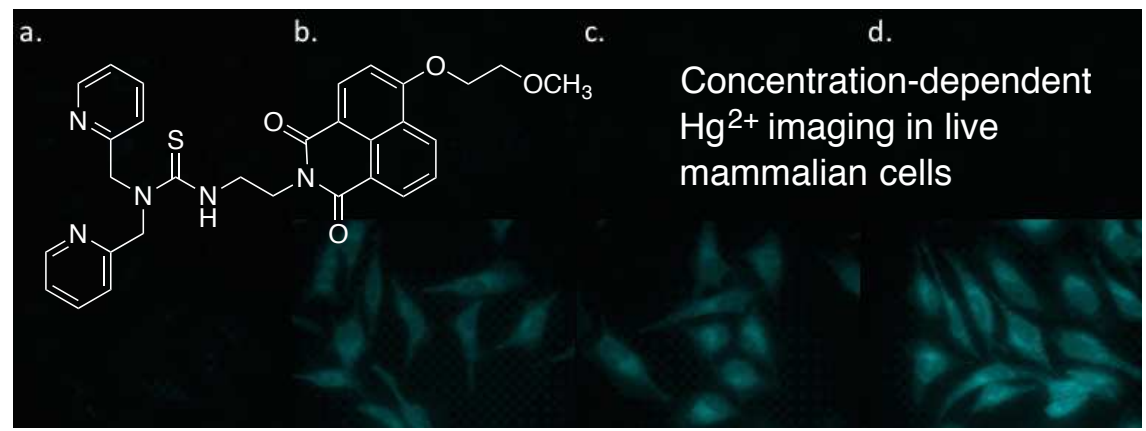

\section{Abstract}

We report three significant advances in the use of thioureas as reporting elements for metal-responsive fluorescent chemosensors. First, based on the crystal structure of a chemosensor analog, we provide a deeper understanding of the details of the thiourea coordination environment. Second, we describe a new generation of chemosensors with higher affinity for $\mathrm{Zn}^{2+}$ and $\mathrm{Cd}^{2+}$ than was 
observed in earlier probes, expanding the scope of this type of probe beyond $\mathrm{Hg}^{2+}$ detection. Third, we show that a thiourea-based chemosensor can be employed for fluorescence microscopy imaging of $\mathrm{Hg}^{2+}$ ion concentrations in living mammalian cells.

\section{Introduction}

As an analytical technique, fluorescence is remarkable for combining great sensitivity with ease of measurement. A central liability is that few analytes of interest are intrinsically fluorescent. This discrepancy has driven the development of fluorescent chemosensors, molecules which convert reversible association with a non-fluorescent analyte into a fluorescence response. ${ }^{1}$ Fluorescent chemosensor development has been particularly effective for metallic species, and selective probes for several metal ions of biological and environmental relevance (e.g. $\mathrm{Ca}^{2+}, \mathrm{Zn}^{2+}$ and $\mathrm{Hg}^{2+}$ ) are now available. ${ }^{2-4}$

The dominant approach to turning reversible metal binding into a fluorescence response is the disruption of the electronic interaction between a nitrogen atom lone pair and a proximal fluorophore via metal coordination by nitrogen. ${ }^{1}$ Most common are the use of benzylic amine-fluorophore conjugates, in which photoinduced electron transfer (PET) from nitrogen quenches fluorescence, and anilinic fluorophores, in which the nitrogen lone pair is engaged in the formation of an intramolecular charge transfer (ICT) excited state. In the former case, 
protonation or coordination suppresses quenching and leads to enhanced emission. In the latter, protonation or coordination leads primarily to variation in the fluorophore emission wavelength, although concomitant intensity variation is not uncommon.

While these nitrogen-centric motifs have proven quite general, ${ }^{1}$ reliance on nitrogen coordination for signaling possesses two characteristic shortcomings: false positive signaling resulting from protonation (i.e. $\mathrm{pH}$ sensitivity) and an exclusive reliance on nitrogen coordination chemistry for signaling.

In an effort to address these issues, we have worked to develop sulfur-based functional groups as reporting elements, and have recently reported the use of sulfoxides and thioureas to this end. ${ }^{5,6}$ Building on our first generation of thioureanaphthalimide conjugates, ${ }^{6}$ we describe here a second generation of PET-based thiourea probes with high affinities for metal ions in aqueous media, ${ }^{7,8}$ and show that they are both insensitive to excess acid and can be applied in cellular imaging.

\section{Results and Discussion}

First Generation Thiourea Probes

Our validation of thioureas as PET quenchers in metal-responsive fluorescent chemosensors has so far relied on naphthalimide chromophores because of their synthetic accessibility, chemical robustness and visible emission. ${ }^{9}$ We have found that fluorescent chemosensors MePic and DiPic (Figure 1) have low 
intrinsic quantum yields due to PET quenching of fluorescence emission by the thioureas (Figure 2) ${ }^{6}$ Emission from the pendant naphthalimide reporter can be recovered by metal ion coordination of the thiourea (Table 1 ), with up to 20 -fold fluorescence enhancement. The addition of a large excess of $\mathrm{H}^{+}$(TFA) did not produce any change in the fluorescence emission of MePic or DiPic, validating our hypothesis that, in contrast to the amine-based probes described above, thioureas would provide $\mathrm{H}^{+}$-independent signaling. Of the range of metal ions screened, the most significant fluorescence enhancements were observed for the $\mathrm{d}^{10}$ cations $\mathrm{Zn}^{2+}, \mathrm{Cd}^{2+}$ and $\mathrm{Hg}^{2+}$, although MePic provides a modest response to $\mathrm{Pb}^{2+}$ as well. Of these, $\mathrm{Hg}^{2+}$ was by far the most tightly bound (Table 2), and the DiPic $\cdot \mathrm{Hg}^{2+}$ complex was found to form with $\mathrm{K}_{\mathrm{d}} \leq 15 \mathrm{nM}$ in 9:1 $\mathrm{H}_{2} \mathrm{O}: \mathrm{CH}_{3} \mathrm{CN}$. ${ }^{6,10}$

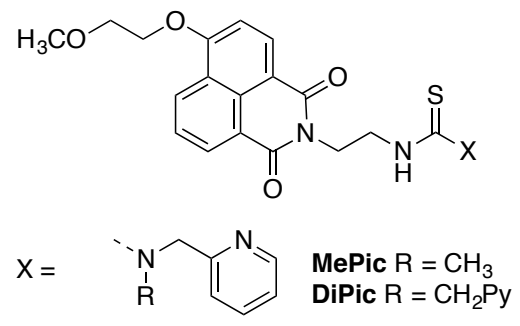

Figure 1. Fluorescent chemosensors MePic and DiPic. (Py = 2-pyridyl.)

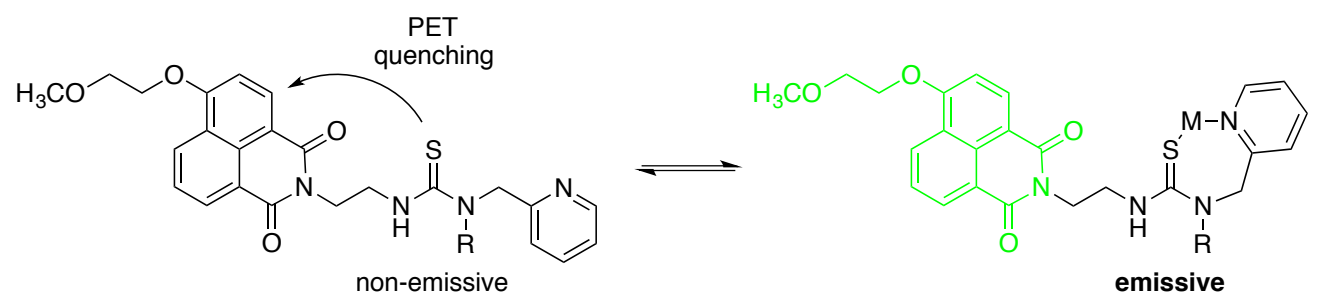

Figure 2. Fluorescent chemosensing with MePic and DiPic. 
Table 1. Values of $\left(\mathrm{I} / \mathrm{I}_{0}\right)_{\max }$ and $\phi_{\max }$ for titrations of MePic and DiPic. ${ }^{a}$

\begin{tabular}{|c|c|c|c|c|}
\hline & $\mathrm{Zn}^{2+}$ & $\mathrm{Cd}^{2+}$ & $\mathrm{Hg}^{2+}$ & $\mathrm{Pb}^{2+}$ \\
\hline \multicolumn{5}{|l|}{$\mathrm{CH}_{3} \mathrm{OH}^{b}$} \\
\hline MePic & $20.5(0.62)$ & $21.7(0.65)$ & $19.0(0.57)$ & $6.3(0.19)$ \\
\hline DiPic & $13.0(0.65)$ & $5.0(0.25)$ & $7.4(0.37)$ & $-{ }^{c}$ \\
\hline \multicolumn{5}{|l|}{$\mathrm{H}_{2} \mathrm{O}^{d}$} \\
\hline MePic & $9.3(0.28)$ & $4.6(0.14)$ & $4.4(0.13)$ & $-{ }^{c}$ \\
\hline DiPic & $5.7(0.29)$ & $4.5(0.23)$ & $8.6(0.43)$ & $-{ }^{c}$ \\
\hline \multicolumn{5}{|c|}{${ }^{a} \phi_{\max }$ in parentheses. $\phi_{\max }=\phi_{\text {initial }} \times\left(1 / I_{0}\right)_{\max } . \phi_{0}($ MePic $)=0.03 ; \phi_{0}($ DiPic $)=0.05$} \\
\hline \multicolumn{5}{|c|}{${ }^{b}$ Titrations in $\mathrm{CH}_{3} \mathrm{OH}$ at $3.3 \mu \mathrm{M}$ chemosensor. } \\
\hline \multicolumn{5}{|c|}{${ }^{c}$ No detectable fluorescence response. } \\
\hline \multicolumn{5}{|c|}{${ }^{d}$ Titrations in 9:1 $\mathrm{H}_{2} \mathrm{O}: \mathrm{CH}_{3} \mathrm{OH}$ at $3.3 \mu \mathrm{M}$ chemosensor. } \\
\hline
\end{tabular}

Table 2. Apparent $\log K_{d}(M)$ for titrations of MePic and DiPic.

$$
\mathrm{Zn}^{2+} \mathrm{Cd}^{2+} \mathrm{Hg}^{2+} \mathrm{Pb}^{2+}
$$

$\mathrm{CH}_{3} \mathrm{OH}^{a}$

$\begin{array}{lllll}\text { MePic } & -3.2 & -3.2 & -5.8 & -2.5\end{array}$

DiPic $\quad-2.9-3.1 \quad-6.1 \quad-{ }^{b}$

$\mathrm{H}_{2} \mathrm{O}^{c}$

$\begin{array}{lllll}\text { MePic } & -1.1 & -2.1 & -5.9 & -{ }^{b}\end{array}$

DiPic $\quad-0.9 \quad-2.3 \quad-6.0^{d}-{ }^{b}$

\footnotetext{
${ }^{a}$ Titrations in $\mathrm{CH}_{3} \mathrm{OH}$ at $3.3 \mu \mathrm{M}$ chemosensor.

${ }^{b}$ No detectable fluorescence response.
} 
${ }^{c}$ Titrations in 9:1 $\mathrm{H}_{2} \mathrm{O}: \mathrm{CH}_{3} \mathrm{OH}$ at $3.3 \mu \mathrm{M}$ chemosensor.

${ }^{d}$ Lower concentration titrations reveal that this $\log K_{d}$ is at least -7.8 . See ref. 6 .

While the metal ion affinities of MePic and DiPic are similar, there is significant variation in maximum quantum yield, which reflects details of the thiourea coordination geometry that are not yet fully understood. We have obtained a crystal structure of the $1: 1$ complex of $\mathrm{ZnCl}_{2}$ and a truncated analog of DiPic in which the fluorophore-bearing sidechain is replaced by a phenyl group (Figure 3). ${ }^{11}$ The structure reveals a near-planar thiourea and coordination of the metal center by a single pyridine unit. Notably, the coordinated zinc atom is located significantly out of the thiourea plane, with an N-C-S-Zn dihedral angle of $57.40(14)^{\circ}$. Bis(thiourea) zinc chloride is known to have zinc coordinated in the plane of the thiourea, ${ }^{12}$ consistent with $\sigma$ coordination by an $\mathrm{sp}^{2}$-hybridized $\mathrm{S}$ atom - presumably the intrinsically preferred geometry. The observed deviation from in-plane coordination must be a consequence of geometric constraints imposed by the ring formation required for coordination of the picolyl group. From a functional point of view, these observations indicate that the coordination geometry responds strongly to structural details of the chelating group, which foreshadows the modulation of metal ion affinity and fluorescence response by ligand variation. 


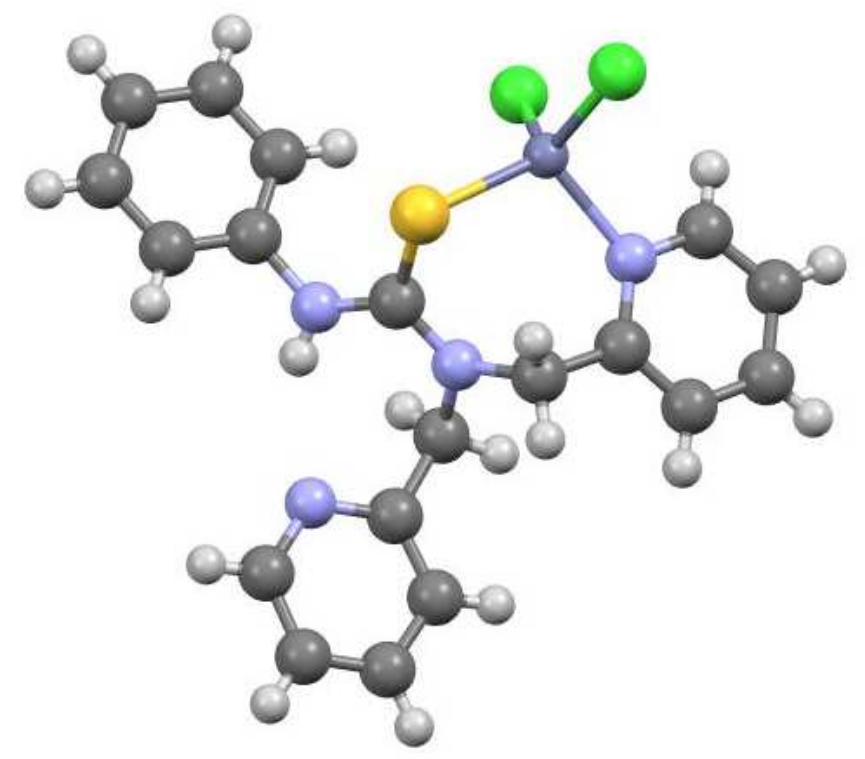

Figure 3. The molecular structure of the $1: 1$ complex between $\mathrm{ZnCl}_{2}$ and a truncated analog of DiPic.

Consistent with the crystal structure, all solution phase titrations of MePic and DiPic indicated 1:1 ligand:metal stoichiometry. ${ }^{6}$ The $\mathrm{Hg}^{2+}$ affinity is sufficient to warrant evaluation of these probes in environmental samples, and it will be shown that DiPic is suitable for use in cellular imaging (vide infra).

A limitation of these first generation fluorescent chemosensors is that the nitrogen atoms of the thiourea remain conjugated to and coplanar with the thiocarbonyl. As a result, the thiourea nitrogen centers are not available for coordination, and only one of the distal $\mathrm{N}$-substituents can participate in cooperative metal binding with the thiourea - as can be seen in the crystal structure (Figure 3). This accounts for the relatively low affinity observed for $\mathrm{Zn}^{2+}$ despite the presence of the high $\mathrm{Zn}^{2+}$-affinity dipicolyl fragment in DiPic, and for 
the similarities in metal affinity between MePic and DiPic. In conjunction with the induced deviation from optimal thiourea coordination discussed above, overcoming this limitation clearly requires more extended ligand domains with a greater degree of flexibility in order to accommodate alternate coordination geometries.

\section{Second Generation Thiourea Probes}

In order to increase the flexibility and coordination denticity of the metal binding domains, analogs with ethylene diamine (En) spacers, EnMePic and EnDiPic, were prepared. In these molecules, the picolyl-bearing nitrogen is no longer conjugated to the thiocarbonyl, removing the associated geometric constraint and freeing the lone pair for binding (Figure 4; Scheme 1). Mono-Boc-protected ethylenediamine was either dialkylated to form the dipicolyl derivative (1) or monoalkylated by reductive amination $(3) .{ }^{13}$ In the latter case, $\mathrm{N}$-methylation provided the requisite protected diamine. ${ }^{14}$ Following removal of the Boc group, the free amines $\left(\mathrm{RNH}_{2} ; \mathbf{2}, \mathbf{4}\right)$ were reacted with a common imidazolyl thiourea (5), described previously, ${ }^{6}$ to afford EnMePic or EnDiPic in modest yield. ${ }^{15}$

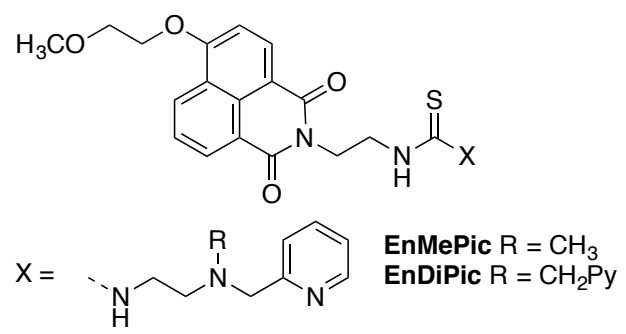

Figure 4. EnMePic and EnDiPic. 


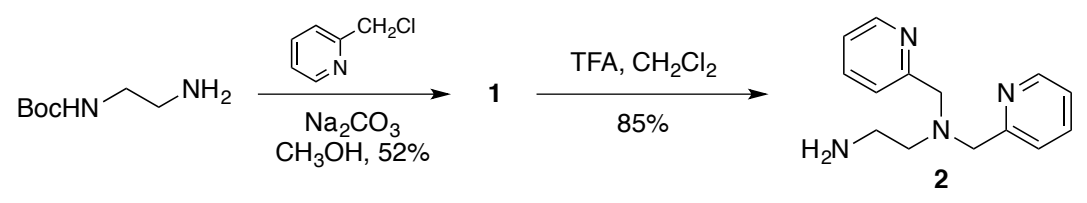

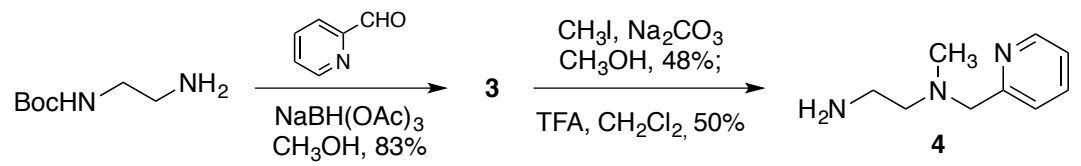

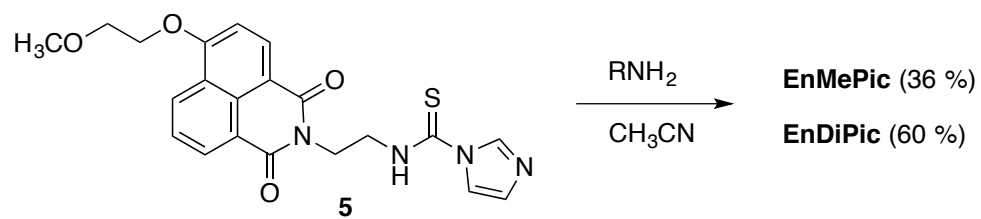

Scheme 1. Preparation of EnMePic and EnDiPic.

\section{Metal Ion Titrations}

With the new probes in hand, metal ion titrations were performed in $\mathrm{CH}_{3} \mathrm{OH}$ with $\mathrm{Na}^{+}, \mathrm{K}^{+}, \mathrm{Mg}^{2+}, \mathrm{Ca}^{2+}, \mathrm{Ag}^{+}, \mathrm{Zn}^{2+}, \mathrm{Cd}^{2+}, \mathrm{Hg}^{2+}$ and $\mathrm{Pb}^{2+}$. Metal solutions were prepared from the corresponding metal chlorides, nitrates or perchlorates. The $\mathrm{CH}_{3} \mathrm{OH}$ solutions (as opposed to aqueous) were chosen for initial evaluation to allow comparison with previous data and identify binding events too weak to be observed with $\mathrm{H}_{2} \mathrm{O}$ as the competing solvent.

Metal ion response was observed for $\mathrm{Ag}^{+}$, the $\mathrm{d}^{10}$ metals and $\mathrm{Pb}^{2+}$, but not alkaline or alkaline earth cations. $\mathrm{Ag}^{+}, \mathrm{Zn}^{2+}, \mathrm{Cd}^{2+}, \mathrm{Hg}^{2+}$ and $\mathrm{Pb}^{2+}$ titrations were then repeated in 9:1 $\mathrm{H}_{2} \mathrm{O}: \mathrm{CH}_{3} \mathrm{OH}$ (Tables 3,4$) \cdot{ }^{11,16}$ Focusing on the aqueous titrations, the magnitude of fluorescence response, represented by $\left(1 / I_{0}\right)_{\max }$, is generally lower than in $\mathrm{CH}_{3} \mathrm{OH}$, and the responses to $\mathrm{Ag}^{+}$and $\mathrm{Pb}^{2+}$ are negated, as indicated by $\log K_{d}$ values too high $(>-1)$ to be accurately determined. No 
fluorescence enhancement for EnMePic or EnDiPic is observed at $\mathrm{pH}$ as low as 5.5. ${ }^{17}$ The response of EnMePic in aqueous solution is diminished relative to MePic (e.g. there is no response to aqueous $\mathrm{Cd}^{2+}$ ). In contrast, the enhancements seen with EnDiPic are comparable or superior to those for DiPic, and are uniformly great enough $\left(1 / I_{0}>5\right)$ to be potentially useful (Table 3$)$. EnMePic and EnDiPic retain their high affinity for $\mathrm{Hg}^{2+}$ in $9: 1 \mathrm{H}_{2} \mathrm{O}: \mathrm{CH}_{3} \mathrm{OH}$, but EnDiPic now has pronounced affinity for $\mathrm{Zn}^{2+}$ and $\mathrm{Cd}^{2+}$ as well (Table 4), exceeding the affinity for $\mathrm{Hg}^{2+}$. The $\log \mathrm{K}_{\mathrm{d}}$ values determined from the titrations are at the limit of measurement for the current reporting fluorophore, which is not bright enough to allow data acquisition below $\sim 1 \mu \mathrm{M}$ without repeat measurement. As a result, we think that the actual affinities are greater than the determined values, although the relative affinities are likely correct. For reasons discussed below, we have not pursued lower concentration measurements. The stoichiometry of the $\mathrm{Hg}^{2+}$ and $\mathrm{Cd}^{2+}$ complexes are $1: 1$, as determined by Job plot and/or Hill coefficient. ${ }^{18,19}$ While EnMePic $\cdot \mathrm{Zn}^{2+}$ is also a $1: 1$ complex, EnDiPic $\cdot \mathrm{Zn}^{2+}$ has 2:1 L:M stoichiometry.

Table 3. Values of $\left(1 / l_{0}\right)_{\max }$ and $\phi_{\max }$ for titrations of EnMePic and EnDiPic. ${ }^{a}$

$$
\mathrm{Zn}^{2+} \quad \mathrm{Cd}^{2+} \quad \mathrm{Hg}^{2+} \quad \mathrm{Ag}^{+} \quad \mathrm{Pb}^{2+}
$$

$\mathrm{CH}_{3} \mathrm{OH}^{b}$

EnMePic $7.4(0.22) \quad 5.1(0.15) \quad 6.3(0.19) \quad 5.2(0.16) \quad-$

EnDiPic $\quad 7.4(0.30) \quad 3.2(0.13) \quad 9.0(0.36) \quad 2.4(0.10) \quad 1.6(0.06)$ 
$\mathrm{H}_{2} \mathrm{O}^{c}$

EnMePic $1.9(0.06) \quad-^{d} \quad 2.5(0.08) \quad-^{d} \quad \quad \quad-^{d}$

EnDiPic $11.2(0.45) \quad 5.3(0.21) \quad 7.4(0.30) \quad-^{d} \quad-^{d}$

${ }^{a} \phi_{\max }=\phi_{\text {initial }} \times\left(\mathrm{I} / \mathrm{I}_{0}\right)_{\max } \cdot \phi_{\max }$ in parentheses. $\phi_{0}($ EnDiPic $)=0.04 ; \phi_{0}($ EnMePic $)=0.03$.

${ }^{b}$ Titrations in $\mathrm{CH}_{3} \mathrm{OH}$ at $3.3 \mu \mathrm{M}$ chemosensor.

${ }^{c}$ Titrations in 9:1 $\mathrm{H}_{2} \mathrm{O}: \mathrm{CH}_{3} \mathrm{OH}$ at $3.3 \mu \mathrm{M}$ chemosensor.

${ }^{d}$ No detectable fluorescence response.

Table 4. Apparent $\log K_{d}(M)$ for titrations of EnMePic and EnDiPic.

$$
\mathrm{Zn}^{2+} \mathrm{Cd}^{2+} \mathrm{Hg}^{2+} \mathrm{Ag}^{+} \mathrm{Pb}^{2+}
$$

$\mathrm{CH}_{3} \mathrm{OH}^{a}$

EnMePic $\quad-5.0 \quad-6.9 \quad-5.9 \quad-5.6 \quad-^{c}$

EnDiPic $\quad-7.1 \quad-7.0 \quad-6.0 \quad-5.7 \quad-5.4$

$\mathrm{H}_{2} \mathrm{O}^{b}$

EnMePic $-2.4 \quad-^{c} \quad-5.9 \quad-^{c} \quad-^{c}$

EnDiPic $\quad-6.9 \quad-7.2 \quad-6.1 \quad-^{c} \quad-^{c}$

\footnotetext{
${ }^{a}$ Titrations in $\mathrm{CH}_{3} \mathrm{OH}$ at $3.3 \mu \mathrm{M}$ chemosensor.

${ }^{b}$ Titrations in 9:1 $\mathrm{H}_{2} \mathrm{O}: \mathrm{CH}_{3} \mathrm{OH}$ at $3.3 \mu \mathrm{M}$ chemosensor.

${ }^{c}$ No detectable fluorescence response.
}

There is not a clear correlation between metal ion affinity and the magnitude of fluorescence response. This is consistent with a complexation model in which the affinity is determined by the ethylenediamine fragment and the fluorescence 
response reflects the details of a second intramolecular equilibrium involving coordination of the thiourea (Figure 5). We have previously observed that thioureas have a low intrinsic affinity for metal ions, allowing us to exclude direct thiourea coordination as a significant process. ${ }^{6}$

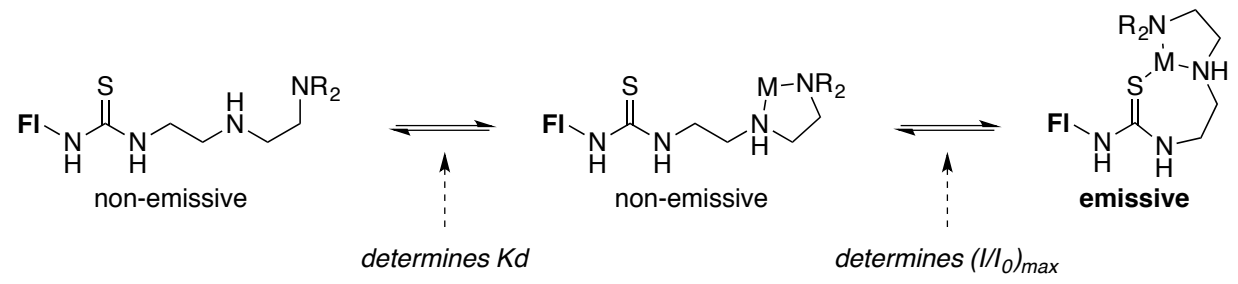

Figure 5. Proposed model for metal ion coordination. $(\mathrm{FI}=$ fluorophore; $\mathrm{M}=$ metal cation.)

The affinities and intensity of fluorescence response of EnDiPic would appear to set the stage for applied measurements. As it turns out, although the compounds are entirely stable on the timescale of our titrations, ${ }^{20}$ we find that EnMePic and EnDiPic degrade over the course of a day in solution and 1-2 weeks as isolated solids. The degradation leads to the formation of complex mixtures of polar material, and appears to involve intramolecular cyclization coupled with dealkylation to form cyclic guanidine species. This conclusion is based on the high polarity and the MS analysis of crude degraded material; we have not yet been able to isolate purified degradation products. ${ }^{21}$

Cellular Assays 
We are unable to deploy EnDiPic in cellular assays due to its instability on the assay timescale. However, we have evaluated DiPic as a probe for $\mathrm{Hg}^{2+}$ in living human cells, $\mathrm{Hg}^{2+}$ being a logical starting point based on the high affinity and selectivity of DiPic for this ion. We found that DiPic is sufficiently membrane permeant to enter HeLa cells, and that it allows visualization of the presence of $\mathrm{Hg}^{2+}$ in a concentration dependent manner. ${ }^{11} \mathrm{HeLa}$ cells were incubated with DiPic $(20 \mu \mathrm{M})$ overnight in standard DMEM growth media, followed by treatment with $\mathrm{HgCl}_{2}(200 \mu \mathrm{M})$ for 10 minutes, followed by fluorescence imaging. In the absence of either DiPic or $\mathrm{Hg}^{2+}$ ions, no detectable fluorescence was observed, similar to that of control cells treated with DMSO only (Figure 6a-c). However, upon treatment with both compound DiPic and $\mathrm{HgCl}_{2}$, a significant increase in fluorescence appeared throughout the cells, but predominantly in the cytoplasm (Figure 6d). This demonstrates that the sensor DiPic is capable of detecting $\mathrm{Hg}^{2+}$ in live human cells. Moreover, DiPic successfully detected $\mathrm{Hg}^{2+}$ ions at lower concentrations of 50 and $100 \mu \mathrm{M}$ and the fluorescence intensity showed $\mathrm{Hg}^{2+}$ concentration dependence. ${ }^{11}$ 


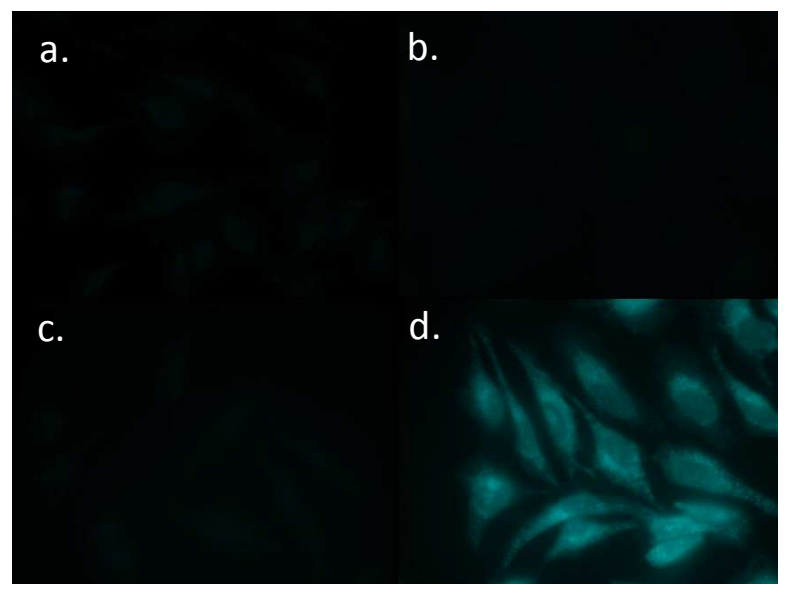

Figure 6. Fluorescence images of HeLa cells treated with DiPic and $\mathrm{HgCl}_{2}$. (a) HeLa cells treated with a DMSO control overnight at $37^{\circ} \mathrm{C}$. (b) Cells treated with a DMSO control followed by $\mathrm{HgCl}_{2}(200 \mu \mathrm{M})$ for $10 \mathrm{~min}$ at $37{ }^{\circ} \mathrm{C}$. (c) Cells incubated with DiPic $(20 \mu \mathrm{M})$ overnight at $37^{\circ} \mathrm{C}$. (d) Cells treated with DiPic (20 $\mu \mathrm{M})$ followed by $\mathrm{HgCl}_{2}(200 \mu \mathrm{M})$ for $10 \mathrm{~min}$ at $37^{\circ} \mathrm{C}$. Imaging was performed on a Zeiss Axio Observer inverted microscope using a $63 \times$ objective and excitation and emission wavelengths of $365 \mathrm{~nm}$ and $445 / 50 \mathrm{~nm}$, respectively.

While the practical value of imaging $\mathrm{Hg}^{2+}$ in biological systems may be limited, ${ }^{4}$ these data validate the use of PET-based thiourea probes in live cells, providing a solid precedent for the design and evaluation of future thiourea probes for relevant trace thiophilic ions, e.g., $\mathrm{Fe}^{2+}$ or $\mathrm{Cr}^{3+} .22$

\section{Next Generation Thiourea Probes}

Two important issues must be addressed in the next generation of thiourea probes: enhancement of stability, and brightness of the reporting fluorophore. The need to improve stability is self-evident; we expect that, as observed with 
first generation fluorophores, ${ }^{6} \mathrm{~N}$-methylation of the thiourea will improve stability. The use of more absorptive fluorophores will allow lower concentration measurements.

\section{Conclusions}

We have shown that thiourea-naphthalimide conjugates with extended binding domains function as metal-responsive fluorescent chemosensors in aqueous media. They are capable of providing a useful $\left(1 / /_{0}>5\right)$ turn-on response to $\mathrm{Zn}^{2+}$, $\mathrm{Cd}^{2+}$ and $\mathrm{Hg}^{2+}$ with at least high-nM sensitivity. In parallel, a previously reported thiourea has been shown to be a viable optical imaging agent for $\mathrm{Hg}^{2+}$ in live cells. Sufficient structural understanding has been attained to allow design of the next generation of improved thiourea-based fluorescent chemosensors, which should exhibit enhanced stability and improved measurement sensitivity, and be suitable for environmental and further cellular applications.

\section{Experimental Section}

\section{General Notes}

Imidazolyl thiourea 5, DiPic and MePic were prepared as previously described. ${ }^{6}$ All other reagents were used as received. Synthetic procedures were carried out under an inert atmosphere, in dry solvent, using standard Schlenk techniques, unless otherwise noted. Flash chromatographic purification was performed using silica gel Merck 60 (particle size $0.040-0.063 \mathrm{~mm}$ ) packed in glass columns; eluting solvent for each purification was determined by thin layer chromatography 
(TLC). Analytical thin-layer chromatography was performed using Merck TLC silica gel 60 F254 or Macherey-Nagel POLYGRAM ALOX N/UV254.

${ }^{1} \mathrm{H}$ NMR chemical shifts are reported in parts per million (ppm) relative to the solvent residual peak $\left(\mathrm{CDCl}_{3}, 7.26 \mathrm{ppm}\right)$. Multiplicities are given as: $\mathrm{s}$ (singlet), $\mathrm{d}$ (doublet), t (triplet), q (quartet), dd (doublet of doublets), m (multiplet), and the coupling constants, $\mathrm{J}$, are given in $\mathrm{Hz} .{ }^{13} \mathrm{C}$ NMR chemical shifts are reported relative to the solvent residual peak $\left(\mathrm{CDCl}_{3}, 77.0 \mathrm{ppm}\right)$. HRMS data were acquired on Bruker maXis UHPLC-HR-MS QTOF instrument with an ESI source. All synthetic products were non-crystalline (oils or sticky solids), precluding melting point determination. Fluorescence measurements were carried out in spectroscopic grade $\mathrm{CH}_{3} \mathrm{OH}$ using $450 \mathrm{~W}$ Xenon lamp excitation with $1 \mathrm{~nm}$ excitation and $1 \mathrm{~nm}$ emission slit widths. Emission spectra were obtained by exciting at the longest-wavelength absorption maxima. For extinction coefficient determination, four independent solutions of different concentration were prepared, with absorption between 0.04-0.10 AU. The value of $\varepsilon$ was calculated by linear least-squares fitting of plots of $A$ vs. concentration. All fits gave $R^{2}$ values of $\geq 0.98$. Quantum yields for EnMePic and EnDiPic were determined by standard methods, ${ }^{11,23}$ using anthracene $(\phi=0.30)$ in $\mathrm{CH}_{3} \mathrm{OH}^{24}$ The samples were diluted to optical transparency $(A \leq 0.05)$, and the integrated emission intensity was compared to an iso-absorptive solution of the standards in degassed solvent. Metal ion titrations were performed as previously described, using metal solutions prepared with spectroscopy grade $\mathrm{CH}_{3} \mathrm{OH}$ or unbuffered, 
purified $\mathrm{H}_{2} \mathrm{O}{ }^{6}$

\section{Synthetic Procedures}

\section{N,N-di-(2-picolyl)-N'-Boc-ethylenediamine (1):}

2-Chloromethylpyridine hydrochloride (451 mg, $2.75 \mathrm{mmol})$ and $\mathrm{Na}_{2} \mathrm{CO}_{3}(530 \mathrm{mg}$, $5.00 \mathrm{mmol}$ ) were added to a solution of $\mathrm{N}$-Boc-1,2-diaminoethane (200 mg, 1.25 $\mathrm{mmol})$ in methanol $(20 \mathrm{~mL})$, and the reaction mixture was heated to reflux for 48 hours. A $2 \mathrm{~N}$ solution of $\mathrm{NaOH}(20 \mathrm{~mL})$ was added and the product was extracted with dichloromethane. The organic phase was washed with brine, dried over $\mathrm{MgSO}_{4}$ and concentrated under vacuum. The crude product was purified by column chromatography $\left(\mathrm{Al}_{2} \mathrm{O}_{3}\right.$; eluent: hexanes $/ \mathrm{CH}_{2} \mathrm{Cl}_{2}, 1: 1 \rightarrow \mathrm{CH}_{2} \mathrm{Cl}_{2} / \mathrm{MeOH}$, $99: 1)$ to give the product as a brown-yellow oil (220 mg, 52\%). Spectroscopic data were consistent with those previously reported. ${ }^{13}$

${ }^{1} \mathrm{H}$ NMR $\left(\delta \mathrm{ppm}, 400 \mathrm{MHz}, \mathrm{CDCl}_{3}\right): 8.55$ (ddd, $\left.2 \mathrm{H}, J=4.9, J=1.8, J=0.9\right), 7.64$ (td, 2H, $J=7.6, J=1.8), 7.43(\mathrm{~d}, 2 \mathrm{H}, J=7.8), 7.16$ (ddd, 2H, $J=7.5, J=4.9, J=$ 1.2), $5.80(\mathrm{~s}, 1 \mathrm{H}), 3.89(\mathrm{~s}, 4 \mathrm{H}), 3.25-3.22(\mathrm{~m}, 2 \mathrm{H}), 2.75-2.72(\mathrm{~m}, 2 \mathrm{H}), 1.44(\mathrm{~s}, 9 \mathrm{H})$.

${ }^{13} \mathrm{C}$ NMR (ס ppm, $125 \mathrm{MHz}, \mathrm{CDCl}$ ): 159.2 (2), 156.2, 149.1 (2), 136.5 (2), 123.2 (2), 122.1 (2), 78.8, 60.2 (2), 53.5, 38.5, 28.5 (3). HRMS-ESI: Calculated for $\mathrm{C}_{19} \mathrm{H}_{27} \mathrm{~N}_{4} \mathrm{O}_{2}[\mathrm{M}+\mathrm{H}]^{+} 343.21333$, found 343.21285 , calculated for $\mathrm{C}_{19} \mathrm{H}_{26} \mathrm{~N}_{4} \mathrm{NaO}_{2}$ $[\mathrm{M}+\mathrm{Na}]^{+}$365.19510, found 365.19480. $\mathrm{Rf}_{\mathrm{f}}\left(\mathrm{CH}_{2} \mathrm{Cl}_{2} / \mathrm{MeOH} 99 / 1\right): 0.2$

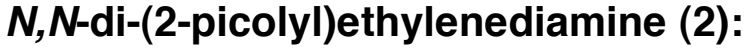

1 (80 mg, $0.23 \mathrm{mmol}$ ) was cooled to $0{ }^{\circ} \mathrm{C}$ in $\mathrm{CH}_{2} \mathrm{Cl}_{2}(2 \mathrm{~mL})$ and trifluoroacetic acid (660 $\mathrm{mg}, 5.85 \mathrm{mmol}$ ) was added. The mixture was allowed to warm to room 
temperature and stirred for 2 hours. $2 \mathrm{~N} \mathrm{NaOH}_{(\mathrm{aq})}$ was added and the aqueous phase extracted with $\mathrm{CH}_{2} \mathrm{Cl}_{2}$. The combined organic fractions were dried over $\mathrm{MgSO}_{4}$ and concentrated. 2 was obtained without purification as a yellow oil (48 $\mathrm{mg}, 85 \%)$. Spectroscopic data were consistent with those previously reported. ${ }^{13}$ ${ }^{1} \mathrm{H}$ NMR ( $\delta$ ppm, $\left.400 \mathrm{MHz}, \mathrm{CDCl}_{3}\right): 8.54(\mathrm{dd}, 2 \mathrm{H}, J=4.9, J=1.3), 7.65(\mathrm{td}, 2 \mathrm{H}, J$ $=7.7, J=1.8), 7.48(\mathrm{~d}, 2 \mathrm{H}, J=7.8), 7.15$ (ddd, $2 \mathrm{H}, J=7.4, J=4.9, J=1.2), 3.86$ (s, 4H), $2.82(\mathrm{t}, 2 \mathrm{H}, J=6.0), 2.69$ (t, $2 \mathrm{H}, J=6.0) .{ }^{13} \mathrm{C}$ NMR $(\delta \mathrm{ppm}, 100 \mathrm{MHz}$, $\mathrm{CDCl}_{3}$ ): 159.5 (2), 149.1 (2), 136.5 (2), 123.0 (2), 122.1 (2), 60.5 (2), 56.3, 39.3. HRMS-ESI: Calculated for $\mathrm{C}_{14} \mathrm{H}_{19} \mathrm{~N}_{4}[\mathrm{M}+\mathrm{H}]^{+} 243.16020$, found 243.16045 .

4-(2-Methoxyethoxy)-N-(ethyl-1-(2-(bis(pyridin-2-ylmethyl)

amino)ethyl) thiourea)naphthalimide (EnDiPic):

5 (53 mg, $0.12 \mathrm{mmol})$; acetonitrile $(5 \mathrm{~mL})$ and $2(30 \mathrm{mg}, 0.12 \mathrm{mmol})$ were combined in $\mathrm{CH}_{3} \mathrm{CN}(5 \mathrm{~mL})$ and stirred for 2 hour at reflux. After removal of the solvent, the crude product was purified by column chromatography $\left(\mathrm{Al}_{2} \mathrm{O}_{3}\right.$, $\mathrm{CH}_{2} \mathrm{Cl}_{2} \rightarrow \mathrm{CH}_{2} \mathrm{Cl}_{2}: \mathrm{MeOH}$ 99:1) to give the product EnDiPic (45 mg, 60\%) as a yellow solid.

${ }^{1} \mathrm{H}$ NMR $\left(\delta \mathrm{ppm}, 400 \mathrm{MHz}, \mathrm{CDCl}_{3}\right): 8.64(\mathrm{dd}, 1 \mathrm{H}, J=1.6, \mathrm{~J}=8.4), 8.59(\mathrm{dd}, 1 \mathrm{H}, J$ $=1.2, J=7.3), 8.57-8.56(\mathrm{~m}, 2 \mathrm{H}), 8.54(\mathrm{~d}, 1 \mathrm{H}, J=8.3), 7.71(\mathrm{dd}, 1 \mathrm{H}, J=7.3, J=$ 8.4), 7.59 (dt, $2 \mathrm{H}, J=1.8, J=7.6), 7.35-7.33(\mathrm{~m}, 2 \mathrm{H}), 7.12-7.09(\mathrm{~m}, 2 \mathrm{H}), 7.04(\mathrm{~d}$, $1 \mathrm{H}, \mathrm{J}=8.3), 4.50-4.48(\mathrm{~m}, 2 \mathrm{H}), 4.45-4.43(\mathrm{~m}, 2 \mathrm{H}), 3.96-3.93(\mathrm{~m}, 4 \mathrm{H}), 3.85(\mathrm{~s}$, 4H), $3.53(\mathrm{~s}, 3 \mathrm{H}), 2.82(\mathrm{t}, 2 \mathrm{H}, J=5.6) .{ }^{13} \mathrm{C} \mathrm{NMR}\left(\delta \mathrm{ppm}, 100 \mathrm{MHz}, \mathrm{CDCl}_{3}\right): 181.9$, 165.4, 164.8, 160.6, 159.0 (2), 149.3 (2), 136.7 (2), 134.0, 132.1, 129.7, 129.5, 
126.2, 123.8, 123.3 (2), 122.3 (2), 122.1, 114.9, 106.3, 70.8, 68.7, 59.9, 59.6, 52.3, 43.0, 39.2. HRMS-ESI: Calculated for $\mathrm{C}_{32} \mathrm{H}_{34} \mathrm{~N}_{6} \mathrm{O}_{4} \mathrm{~S}[\mathrm{M}+\mathrm{H}]+599.24350$, found 599.24344; calculated for $\mathrm{C}_{32} \mathrm{H}_{33} \mathrm{~N}_{6} \mathrm{NaO}_{4} \mathrm{~S}[\mathrm{M}+\mathrm{Na}]_{+} 621.22545$, found 621.22522. $\mathrm{Rf}\left(\mathrm{Al}_{2} \mathrm{O}_{3}, \mathrm{CH}_{2} \mathrm{Cl}_{2}: \mathrm{MeOH}\right.$ 99.5:0.5): 0.25.

\section{$N$-(2-picolyl)-N'-Boc-ethylenediamine (3):}

$\mathrm{N}$-Boc-1,2-diaminoethane $(627 \mathrm{mg}, 3.92 \mathrm{mmol}$ ) was dissolved in methanol (15 $\mathrm{mL})$ and 2-pyridine carboxaldehyde $(350 \mathrm{mg}, 3.27 \mathrm{mmol})$ was added at $0^{\circ} \mathrm{C}$. The reaction mixture was stirred at room temperature for 3 hours, sodium triacetoxyborohydride $(970 \mathrm{mg}, 4.57 \mathrm{mmol})$ was added and the reaction mixture was stirred overnight. The solvent was removed under vacuum and the residue was treated with saturated $\mathrm{Na}_{2} \mathrm{CO}_{3}$. The product was extracted with $\mathrm{CH}_{2} \mathrm{Cl}_{2}$, and the organic phase was dried over $\mathrm{MgSO}_{4}$ and concentrated under vacuum. 3 was obtained as a brown oil (680 mg, 83\%) in sufficient purity for use in the subsequent step. Spectroscopic data were consistent with those previously reported. ${ }^{14}$

${ }^{1} \mathrm{H}$ NMR $\left(\delta \mathrm{ppm}, 400 \mathrm{MHz}, \mathrm{CDCl}_{3}\right): 8.56(\mathrm{dd}, 1 \mathrm{H}, J=5.0,1.2), 7.65(\mathrm{td}, 1 \mathrm{H}, J=$ 7.7, $J=1.8), 7.29(\mathrm{~d}, 1 \mathrm{H}, J=7.8 \mathrm{~Hz}), 7.18(\mathrm{ddd}, 1 \mathrm{H}, J=7.5, J=4.9, J=1.1)$, $5.17(\mathrm{~s}, 1 \mathrm{H}), 3.93(\mathrm{~s}, 2 \mathrm{H}), 3.39-3.36(\mathrm{~m}, 2 \mathrm{H}), 2.82-2.80(\mathrm{~m}, 2 \mathrm{H}), 1.44(\mathrm{~s}, 9 \mathrm{H}) .{ }^{13} \mathrm{C}$ NMR ( $\delta$ ppm, $\left.125 \mathrm{MHz}, \mathrm{CDCl}_{3}\right):$ 158.9, 156.2, 149.4, 136.6, 122.4, 122.2, 79.2, 54.5, 48.8, 40.2, 28.4 (3). $\mathrm{Rf}_{\mathrm{f}}\left(\mathrm{Al}_{2} \mathrm{O}_{3}, \mathrm{CH}_{2} \mathrm{Cl}_{2}: \mathrm{MeOH}\right.$ 99.5:0.5): 0.11

\section{$N$-methyl-N-(2-picolyl)-N'-Boc-ethylenediamine (Boc-protected 4):}

lodomethane (34 mg, $0.239 \mathrm{mmol})$ and sodium carbonate $(85 \mathrm{mg}, 0.80 \mathrm{mmol})$ 
were added to a solution of $3(50 \mathrm{mg}, 0.20 \mathrm{mmol})$ in $\mathrm{CH}_{3} \mathrm{OH}(20 \mathrm{~mL})$ and the reaction mixture was heated to reflux for 72 hours. The solvent was concentrated under vacuum and the crude product was purified by column chromatography $\left(\mathrm{Al}_{2} \mathrm{O}_{3}\right.$, eluent: $\mathrm{CH}_{2} \mathrm{Cl}_{2}$ ). The product was obtained as a light yellow oil (25 mg, $48 \%)$.

${ }^{1} \mathrm{H}$ NMR $\left(\delta \mathrm{ppm}, 400 \mathrm{MHz}, \mathrm{CDCl}_{3}\right): 8.57-8.55(\mathrm{~m}, 1 \mathrm{H}), 7.67(\mathrm{td}, 1 \mathrm{H}, J=7.7, J=$ 1.8), $7.38(\mathrm{~d}, 1 \mathrm{H}, J=7.9), 7.18(\mathrm{dd}, 1 \mathrm{H}, J=7.4, J=3.0), 3.71(\mathrm{~s}, 2 \mathrm{H}), 3.27-3.25$ (m, 2H), 2.59-2.57 (m, 2H), $2.32(\mathrm{~s}, 3 \mathrm{H}), 1.45(\mathrm{~s}, 9 \mathrm{H}) .{ }^{13} \mathrm{C} \mathrm{NMR}(\delta \mathrm{ppm}, 125 \mathrm{MHz}$, $\left.\mathrm{CDCl}_{3}\right):$ 159.0, 156.2, 149.3, 136.6, 123.2, 122.2, 79.2, 63.8, 56.5, 42.4, 38.2, 38.6 (3). HRMS-ESI: Calculated for $\mathrm{C}_{14} \mathrm{H}_{24} \mathrm{~N}_{3} \mathrm{O}_{2}[\mathrm{M}+\mathrm{H}]+266.1863$, found 266.1864. $\mathrm{Rf}$ (aluminium oxide: $\mathrm{CH}_{2} \mathrm{Cl}_{2}$ ): 0.31

\section{$N$-methyl-N-(2-picolyl)ethylenediamine (4):}

$N$-methyl- $N$-(2-picolyl)- $N$ '-Boc-ethylenediamine $(150 \mathrm{mg}, 0.57 \mathrm{mmol})$ was cooled to $0{ }^{\circ} \mathrm{C}$ in $\mathrm{CH}_{2} \mathrm{Cl}_{2}(10 \mathrm{~mL})$ and trifluoroacetic acid $(1.61 \mathrm{~g}, 14.15 \mathrm{mmol})$ was added. The mixture was allowed to warm to room temperature and stirred for 2 hours. $2 \mathrm{~N} \mathrm{NaOH}_{(\mathrm{aq})}$ was added and the aqueous phase extracted with $\mathrm{CH}_{2} \mathrm{Cl}_{2}$. The combined organic fractions were dried over $\mathrm{MgSO}_{4}$ and concentrated. 4 was obtained without purification as a yellow oil (48 $\mathrm{mg}, 50 \%$ ) and used immediately in the next reaction.

${ }^{1} \mathrm{H}$ NMR $(\delta \mathrm{ppm}, 400 \mathrm{MHz}, \mathrm{CDCl} 3):$ 8.57-8.55 $(\mathrm{m}, 1 \mathrm{H}), 7.68-7.64(\mathrm{~m}, 1 \mathrm{H}), 7.38(\mathrm{~d}$, $1 \mathrm{H}, J=7.9), 7.19-7.17(\mathrm{~m}, 1 \mathrm{H}), 3.68(\mathrm{~s}, 2 \mathrm{H}), 2.56-2.54(\mathrm{~m}, 4 \mathrm{H}), 2.26(\mathrm{~s}, 3 \mathrm{H})$. 


\section{naphthalimide (EnMePic):}

5 (103 mg, $0.24 \mathrm{mmol})$; acetonitrile $(5 \mathrm{~mL})$ and $4(40 \mathrm{mg}, 0.24 \mathrm{mmol})$ were combined in $\mathrm{CH}_{3} \mathrm{CN}$ (5 mL) and stirred for 2 hour at reflux. The solvent was removed and the crude product was purified by column chromatography $\left(\mathrm{Al}_{2} \mathrm{O}_{3}\right.$, $\mathrm{CH}_{2} \mathrm{Cl}_{2} \rightarrow \mathrm{CH}_{2} \mathrm{Cl}_{2}: \mathrm{MeOH}$ 99:1) to give the product EnMePic as a yellow solid (45 $\mathrm{mg}, 36 \%)$.

${ }^{1} \mathrm{H}$ NMR ( $\left.\delta \mathrm{ppm}, 400 \mathrm{MHz}, \mathrm{CDCl}_{3}\right): 8.66-8.55(\mathrm{~m}, 3 \mathrm{H}), 8.53(\mathrm{~d}, 1 \mathrm{H}, J=8.3)$, 7.70 (dd, $1 \mathrm{H}, J=7.3, J=8.4), 7.62(\mathrm{td}, 1 \mathrm{H}, J=1.8, J=7.7), 7.34(\mathrm{~d}, 1 \mathrm{H}, J=7.8)$, $7.14(\mathrm{dt}, J=2.9, J=8.1), 7.05(\mathrm{~d}, 1 \mathrm{H}, J=8.3), 4.57-4.36(\mathrm{~m}, 4 \mathrm{H}), 4.01-3.81(\mathrm{~m}$, 4H), $3.73(\mathrm{~s}, 2 \mathrm{H}), 3.52(\mathrm{~s}, 5 \mathrm{H}), 2.71(\mathrm{~s}, 2 \mathrm{H}), 2.31(\mathrm{~s}, 3 \mathrm{H}) .{ }^{13} \mathrm{C}$ NMR $(\delta \mathrm{ppm}, 125$ $\left.\mathrm{MHz}, \mathrm{CDCl}_{3}\right): 182.0,165.4,164.7,160.6$ (2), 149.4, 136.8, 134.0, 132.1, 129.6, 129.6, 126.2, 123.7, 123.4, 122.4, 122.0, 114.8, 106.0, 70.8, 68.6, 63.3, 59.6, 55.4, 53.6, 42.2, 39.1. HRMS-ESI: Calculated for $\mathrm{C}_{27} \mathrm{H}_{32} \mathrm{~N}_{5} \mathrm{O}_{4} \mathrm{~S}[\mathrm{M}+\mathrm{H}]^{+}$522.21695, found 522.21711. $\mathrm{Rf}_{\mathrm{f}}\left(\mathrm{Al}_{2} \mathrm{O}_{3}, \mathrm{CH}_{2} \mathrm{Cl}_{2}: \mathrm{MeOH}\right.$ 99.5:0.5): 0.25.

\section{Cell culture.}

Experiments were performed using HeLa cells (ATCC) cultured in Dulbecco's Modified Eagle Medium (DMEM; Hyclone) supplemented with $10 \%$ fetal bovine serum (FBS; Hyclone) and $2 \%$ penicillin/streptomycin (Mediatech) and maintained at $37^{\circ} \mathrm{C}$ in a $5 \% \mathrm{CO}_{2}$ atmosphere.

\section{Detection of $\mathrm{Hg}^{2+}$ ions in mammalian cells.}


HeLa cells were passaged into an 8-well chamber slide at 10,000 cells/well and were grown overnight at $37^{\circ} \mathrm{C}$. The media was removed and the cells were treated with either a DMSO control (1\% DMSO final concentration) or DiPic (20 $\mu \mathrm{M})$ in DMEM and were incubated overnight at $37^{\circ} \mathrm{C}$. The media was removed and the cells were washed $3 \times$ with PBS $(100 \mu \mathrm{L})$. The cells were then treated with $\mathrm{HgCl}_{2}$ at 0 or $200 \mu \mathrm{M}$ in PBS and were incubated for 10 min at $37^{\circ} \mathrm{C}$. The cells were imaged for fluorescence on a Zeiss Axio Observer inverted microscope using a $63 \times$ objective and filter set 49 (excitation $365 \mathrm{~nm}$, emission $445 / 50 \mathrm{~nm})$.

\section{Acknowledgements}

This work was supported by the Swiss National Science Foundation, the Institute of Organic Chemistry (UZH) and a GlaxoSmithKline graduate fellowship (C. M. C.).

\section{Supporting Information Available}

Supporting Information: Representative absorbance spectra, emission spectra, titration spectra; concentration-dependent $\mathrm{Hg}^{2+}$ imaging in HeLa cells; copies of ${ }^{1} \mathrm{H}$ and ${ }^{13} \mathrm{C}$ NMR spectra; crystallographic data (CIF) for the $\mathrm{ZnCl}_{2}$ complex of the truncated ligand. This material is available free of charge via the Internet at http://pubs.acs.org/. 


\section{References}

1. For representative reviews of fluorescent chemosensors and probes, see: (a) Li, X.; Gao, X.; Shi, W.; Ma, H. Chem. Rev. 2014, 114, 590-659. (b) Formica, M.; Fusi, V.; Giorgi, L.; Micheloni, M. Coord. Chem. Rev. 2012, 256, 170-192. (c) da Silva, A. P.; Uchiyama, S. Top. Curr. Chem. 2011, 300, 1-28. (d) Quang, D. T.; Kim, J. S. Chem. Rev. 2010, 110, 6280-6301. (e) Cho, D.-G.; Sessler, J. L. Chem. Soc. Rev. 2009, 38, 1647-1662. (f) Demchenko, A. P. Introduction to Fluorescence Sensing, Chapter 6, Springer Science: London, 2009 (g) Tsukanov, A. V; Dubanosov, A. D.; Bren, V. A.; Minkin, V. I. Chem. Het. Comp. 2008, 44, 899-923. (h) Callan, J. F.; de Silva, A. P.; Magri, D. C. Tetrahedron 2005, 61, 8551-8588. (i) de Silva, A. P.; Gunaratne, H. Q. N.; Gunnlaugsson, T.; Huxley, A. J. M; McCoy, C. P.; Rademacher, J. T.; Rice, T. E. Chem. Rev. 1997, 97, 15151566.

2. For an overview of fluorescent probes for $\mathrm{Ca}^{2+}$, see: Simpson, A. W. M. Methods in Molecular Biology 2013, 937, 3-36.

3. For an overview of fluorescent $\mathrm{Zn}^{2+}$ detection, see: Huang, Z.; Lippard, S. J. Methods in Enzymology 2012, 505, 445-468.

4. For overviews of fluorescent $\mathrm{Hg}^{2+}$ detection, see: (a) Kim, H. N.; Ren, W. X.; Kim, J. S.; Yoon, J. Chem. Soc. Rev. 2012, 41, 3210-3244. (b) Nolan, E. M.; Lippard, S. J. Chem. Rev. 2008, 108, 3443-3480.

5. Kathayat, R. S.; Finney, N. S. J. Am. Chem. Soc. 2013, 135, 12612-12614. 
6. Vonlanthen, M.; Finney, N. S. J. Org. Chem. 2013, 78, 3980-3988.

7. For reviews of anion coordination by ureas/thioureas, see: (a) Gunnlaugsson, T.; Ali, H. D. P.; Glynn, M.; Kruger, P. E.; Hussey, G. M.; Pfeffer, F. M.; Santos, C. M. G.; Tierney, J. J. Fluor. 2005, 15, 287-299. (b) Amendola, V.; Bonizzoni, M.; Esteban-Gomez, D.; Fabbrizzi, L.; Licchelli, M.; Sancenon, F.; Taglietti, A. Coord. Chem. Rev. 2006, 250, 1451-1470. (c) Gunnlaugson, T.; Glynn, M.; Tocci, G. M.; Kruger, P. E.; Pfeffer, F. M. Coord. Chem. Rev. 2006, 250, 3094-3117. (d) Li, A.F.; Wang, J.-H.; Wang, F.; Jiang, Y.-B. Chem. Soc. Rev. 2010, 39, 3729-3745. (e) Duke, R. M.; Veale, E. B.; Pfeffer, F. M.; Kruger, P. E.; Gunnlaugson, T. Chem. Soc. Rev. 2010, 39, 3936-3953

8. For an early example of a PET-based chemosensor that does not rely on nitrogen, see: da Silva, A. P.; Sandanayake, K. R. A. S. J. Chem. Soc. Chem. Comm. 1989, 1183-1185; for other examples, see esp. ref. 1i.

9. For overviews of the versatility of naphthalimide fluorophores, see ref. $7 e$ and: Banerjee, S.; Veale, E. B.; Phelan, C. M.; Murphy, S. A.; Tocci, G. M.; Gillespie, L. J.; Frimannsson, D. O.; Kelly, J. M.; Gunnlaugsson, T. Chem. Soc. Rev., 2013, 42, 1601-1618.

10. For reports of $\mathrm{Hg}^{2+}$-responsive fluorescent chemosensors based on aminomethylanthracene thioureas, in which PET has been claimed as the operant signaling mechanism: (a) Profatilova, I. A.; Bumber, A. A.; Tolpygin, I. E.; Rybalkin, V. P.; Gribanova, T. N.; Mikhailov, I. E.; Bren, V. A. Russ. J. Gen. 
Chem. 2005, 75, 1774-1781. (b) Tolpygin, I. E.; Shepelenko, E. N.; Revinskii, Y. V.; Tsukanov, A. V.; Dubonosov, A. D.; Bren, V. A.; Minkin, V. I. Russ. J. Gen. Chem. 2010, 80, 756-770.

11. See Supporting Information.

12. Kunchur, N. R.; Truter, M. R. J. Chem. Soc. 1958, 3478-3484.

13. N,N-Dipicolyl(ethylenediamine): (a) Romary, J. K.; Barger, J. D.; Bunds, J. E. Inorg. Chem. 1968, 7, 1142-1145. By reductive amination: (b) Matouzenko, G. S.; Bousseksou, A.; Lecocq, S.; van Koningsbruggen, P. J.; Perrin, M.; Kahn, O.; Collet, A. Inorg. Chem. 1997, 36, 2975-2981. In Boc-protected form: (c) Hanaoka, K.; Kikuchi, K.; Urano, Y.; Nagano, T. J. Chem. Soc., Perkin Trans. 2 2001, 1840-1843.

14. Lim, N. C.; Ewart, C. B.; Bowen, M. L.; Ferreira, C. L.; Barta, C. A.; Adam, M. J.; Orvig, C. Inorg. Chem. 2008, 47, 1337-1345.

15. EnMePic: $\varepsilon=13,800 \mathrm{~cm}^{-1} \mathrm{M}^{-1} ; \phi=0.03 ; \lambda_{\max (\text { abs })}=368 \mathrm{~nm}$ (longestwavelength maximum); $\lambda_{\max (\mathrm{em})}=446 \mathrm{~nm}$. EnDiPic: $\varepsilon=14,500 \mathrm{~cm}^{-1} \mathrm{M}^{-1} ; \phi=$ $0.04 ; \lambda_{\max (\mathrm{abs})}=368 \mathrm{~nm}$ (longest-wavelength maximum); $\lambda_{\max (\mathrm{em})}=446 \mathrm{~nm}$.

16. Binding constants were determined by non-linear least-squares fitting of plots of emission intensity vs log[M] using the program Prism3 (Graphpad, Inc., San Diego, CA).

17. The addition of $\mathrm{HCl}$ to a solutions of EnMePic or EnDiPic do not produce a 
change in fluorescence until $\sim \mathrm{pH} 5$. At this point, the protonated picolylamine begins to serve as an alternate PET acceptor and fluorescence begins to increase. For precedent, see: de Silva, S. A.; Zavaleta, A.; Baron, D. E.; Allam, O.; Isidor, E. V.; Kashimura, N.; Percarpio, J. M. Tetrahedron Lett. 1997, 38, 2237-2240.

18. (a) Connors, K. A. Binding Constants John Wiley \& Sons: New York, 1987. (b) Huang, C. Y. Methods Enzymol. 1982, 87, 509-525.

19. Hill coefficients can provide an indication of binding stoichiometry: (a) Chow, C. C.; Ong, K. M. Dougherty, E. J.; Simons Jr., S. S. Methods Enzymol. 2011, 487, 465-483. However, this approach must be taken with caution; see for example: (b) Lissi, E.; Calderon, C.; Campos, A. Photoch. Photobiol. 2013, 89, $1413-1416$.

20. We have found that EnMePic and EnDiPic can be recovered untransformed following exposure to $\mathrm{Zn}^{2+}$ and $\mathrm{Hg}^{2+}$ for several hours in $\mathrm{CH}_{3} \mathrm{OH}$. This excludes the possibility that fluorescence enhancements are the result of desulfurization of the thiourea. The addition of chelating agents (EDTA or dipicolyl amine) reverses the observed fluorescence enhancements.

21 . There is a precedent for metal-ion induced cyclization of $N$-( $\beta$-aminoethyl) $N$ 'acylthioureas to form cyclic guanidines in the context of chemodosimeters, in which a $\beta$-amino $\mathrm{NH}$ serves as the nucleophile. (See refs. 1a, d.) We had anticipated that the absence of a free $\beta-\mathrm{NH}$ would suppress such cyclization. 
22. For a review of $\mathrm{Fe}^{3+}$-responsive fluorescent chemosensors, see: (a) Chem. Soc. Rev. 2012, 41, 7195-7227. For recent examples of $\mathrm{Cr}^{3+}$-selective fluorescent chemosensors, see: (b) Goswami, S.; Das, A. K.; Maity, A. K.; Manna, A.; Aich, K.; Maity, S.; Saha, P.; Mandal, T. K. Dalton Trans. 2014, 43, 231-239. (c) Goswami, S.; Aich, K.; Das, S.; Das, A. K.; Sarkar, D.; Panja, S.; Mondal, T. K.; Mukhopadhya, S. Chem. Commun. 2013, 49, 10739-10741. (d) Zhao, M.; Ma, L.; Zhang, M.; Cao, W.; Yang, L.; Ma, L.-J. Spectrochim. Acta A 2013, 116, 460465.

23. Lakowicz, J. R. Principles of Fluorescence Spectroscopy; Springer: New York, 2006.

24. Berlman, B. I. Handbook of Fluorescent Spectra; Academic Press: New York, 1965. 